\title{
Probability Model for Looking for a Job Educated Job Seeker at the Labor Market in Central Java Province (Sakernas Data)
}

\author{
Dody Setyadi ${ }^{1, *}$, Karnowahadi $^{2}$, Endang Sulistyani ${ }^{3}$ \\ ${ }^{1}$ Business Administration Department, Politeknik Negeri Semarang, Semarang, Indonesia \\ ${ }^{2}$ Business Administration Department, Politeknik Negeri Semarang, Semarang, Indonesia \\ ${ }^{3}$ Business Administration Department, Politeknik Negeri Semarang, Semarang, Indonesia \\ *Corresponding author. Email: dody.setyadi@polines.ac.id
}

\begin{abstract}
This study aims to determine the work probability model for measuring the probability of looking for job by age, gender, status as head of household, income while looking for job, education level and market wages, using SAKERNAS data and multiple logistic models. This model will examine the significance of the effect of education level, age, gender and market wages on the probability of Work. After being tested, then an estimate is made on the probability of working and the probability of looking for work. The results show that the probability of looking for work is higher for the workforce who are older, have income while looking for work, have junior high school, high school and college education and are in the higher category of market wages. The theoretical implications of the independent variables involved can be used to determine the working probability model because it fits the hypothesis and theory, especially search theory. The resulting policy implications are to encourage the expansion of access to job information and reduce the cost of managing job requirements, expand access to capital for entrepreneurs and adjust wage policies.
\end{abstract}

Keywords: Probability of looking for job, search theory.

\section{INTRODUCTION}

Central Java province which is part of the Republic of Indonesia that has a population of approximately 35 million and a workforce of 29 million. With a percentage of job seekers of $5 \%$, Central Java is a developing region with economic growth in 2011 of 6.03 percent. The high economic growth will result in opening up opportunities for the province to improve the quality of its workforce by providing them with higher education. These efforts result in an increase in the aspirations of educated job seekers so that they are not quicker to work, but must choose jobs that match their inherent characteristics. This has resulted in the length of time educated job seekers are in the search for work. This period In central Java experienced a slow decline in the percentage of unemployment, which was 1.9 percent, even educated unemployment only fell by 1 percent.
The appropriate approach to determine job seeker behavior is to use a theoretical approach which assumes that job seekers while looking for work will pay the cost of looking for work, earn non-market income, accept normally distributed job offers, stop looking for work if the wages offered are equal to The reservation wage is set because it considers that the additional costs incurred must be equal to the additional income he will receive if he has to accept the job at that time [1], [2].

The development of this theory states that the consideration of job seekers is the accumulation of income that will be received during their work if assessed now which will be compared between current job offers and future offers [3], if job seekers accept current jobs then they will have a longer tenure but with lower wages, meaning that if it is accumulated and valued now, it will produce a total income value that is not necessarily higher than the value of income that job seekers will receive if they have to start working 6 months later even though they are paid 
higher wages and shorter tenure [4]. By looking at the assumptions of search theory, delays in deciding to work are usually related to the cost of looking for work, income while looking for work, the reservation wage that is set, and the wages offered. Therefore, the factors that determine job seekers deciding to work or still looking for work (probability of work) are (1) the characteristics of job seekers that can affect the wage, namely education, age, gender; (2) factors that can affect the cost of looking for work, namely the status of job seekers as head of household as an individual internal factor, and the income of job seekers as well as wages offered proxied by market wages as individual external factors. Thus, the problem in determining the effect of the age, gender, status (as head of the household), the income of job seekers during the period of looking for work, education, and market wages on the probability of working in order to determine the probability of looking for work is a problem that will arise and completed in this study. The scope is the job seeker at labor market in central Java Province.

\subsection{Literature Review}

The phenomenon of job seekers or known as frictional unemployment is usually observed in a macro context, so that the occurrence of unemployment or job seekers is generally expressed as excess supply for labor, namely a number of workers who survive at wage levels above the prevailing market wages so that they cannot be accommodated in the labor market as worker. This condition is explained in the general equilibrium theory of the labor market which is depicted in the labor supply and demand curves. The intersection of the supply line for labor that has a positive slope and the demand line for labor that has a negative slope creates a point that describes the number of workers who accept to work at a certain wage level. Furthermore, by paying attention to the theory of labor supply, it can be explained that the relationship between working hours and the level of wages offered will indicate the workforce's decision to choose work or leisure. At a certain wage level, workers no longer want to increase their working hours but prefer leisure, so the figure is expressed in a backward bending supply curve [5]. Job seeker behavior can be explained by a search theory approach, namely a job search theory that will explain whether individuals have to work or want to continue looking for work. Search theory assumes that job seekers will bear the costs while looking for work both in the form of search costs and costs due to lost opportunities, on the other hand they will earn nonmarket income, accept job offers that are normally distributed according to the level of wages offered and job seekers will set reservations. wage as a limit to accept or reject the offered job [1],[2]. In its development, job seekers will consider the income that will be received during their working period if assessed now and job seekers in the labor market are free to choose whether they will work alone, work while looking for work or just look for work [4], so they will consider age. if you want to accept or reject a job offer [6]. The decision to work or not to work will also take into account the expectations of income received during the period of work if it is assessed mathematically now if accepting a job is formulated as follows [3]:

$$
\begin{aligned}
& \mathrm{E}=\sum_{t=0}^{\infty} \beta^{t} W a_{t}(1) \\
& W a=W r+\beta \alpha E W o+\beta(1-\alpha) W a(2)
\end{aligned}
$$

If refuse a job:

$$
\begin{aligned}
& \mathrm{E}=\sum_{t=0}^{\infty} \beta^{\mathrm{t}} \mathrm{Ws} \\
& \mathrm{Ws}=\mathrm{Wu}-\mathrm{C}+\beta(1-\alpha) \mathrm{E}(\mathrm{Wo})
\end{aligned}
$$

When job seekers have to accept Wo or the wages offered, then this condition means that job seekers will maximize value by way of a balance, namely $W a$ equals $W s$ mathematically formulated as follows:

$\mathrm{Ws}=\mathrm{Wa}(5)$

Which means it is described in an algebraic mechanism as follows:

$$
\begin{aligned}
& \mathrm{Wu}-\mathrm{C}+\beta(1-\alpha) E \mathrm{~W}_{\mathrm{o}}=\frac{\mathrm{W}_{\mathrm{r}}+\beta \alpha \mathrm{E} \mathrm{Wo}_{\mathrm{o}}}{(1-\beta(1-\alpha))}(6) \\
& (1-\beta(1-\alpha))(\mathrm{Wu}-\mathrm{C}+\beta(1-\alpha) \mathrm{E} \mathrm{Wo})=\mathrm{Wr}+\beta \alpha \mathrm{E} \mathrm{Wo}_{\mathrm{o}}(7) \\
& \mathrm{Wr}+\beta \alpha \mathrm{E} \mathrm{Wo}_{0}=(1-\beta(1-\alpha)) \mathrm{Wu}-(1-\beta(1-\alpha)) \mathrm{C}+(1- \\
& \beta(1-\alpha)) \beta(1-\alpha) \text { E Wo (8) } \\
& \mathrm{Wr}=(1-\beta(1-\alpha)) \mathrm{Wu}-(1-\beta(1-\alpha)) \mathrm{C}+(1-\beta(1-\alpha)) \\
& \beta(1-\alpha) \text { E Wo - } \beta \alpha \text { E Wo (9) }
\end{aligned}
$$$$
\mathrm{Wr}=(1-\beta(1-\alpha)) \mathrm{Wu}-(1-\beta(1-\alpha)) \mathrm{C}+(1-\beta(1-\alpha))(\beta
$$$$
\text { E Wo }-\beta \alpha \text { E Wo) }-\beta \alpha \text { E Wo (10) }
$$$$
\text { if } \Phi=(1-\beta(1-\alpha))(11)
$$

then :

$$
\begin{aligned}
& W r=\Phi(W u-C+\beta E W o-\beta \alpha E \text { Wo })-\beta \alpha E \text { Wo (12) } \\
& \mathrm{Wr}=\Phi \mathrm{Wu}-\Phi \mathrm{C}+\Phi \beta \mathrm{E} \mathrm{Wo}-\Phi \beta \alpha \mathrm{E} \mathrm{Wo}-\beta \alpha \mathrm{E} \mathrm{Wo}_{\mathrm{o}}(13) \\
& \mathrm{Wr}=\Phi \mathrm{Wu}-\Phi \mathrm{C}+\Phi \beta \mathrm{E} \mathrm{Wo}-\beta \alpha \mathrm{E} \mathrm{Wo}(\Phi-1)(14) \\
& \mathrm{Wr}=\Phi(\mathrm{Wu}-\mathrm{C}+\beta \mathrm{E} \mathrm{Wo})-(\Phi-1) \beta \alpha \mathrm{E} \text { Wo (15) } \\
& \mathrm{Wr}=\Phi(\mathrm{Wu}-\mathrm{C}+\beta \mathrm{E} \mathrm{Wo})-((1-\beta(1-\alpha))-1) \beta \alpha \mathrm{E} \mathrm{Wo}_{\mathrm{o}}
\end{aligned}
$$


$\mathrm{Wr}=\Phi(\mathrm{Wu}-\mathrm{C}+\beta \mathrm{E} \mathrm{Wo})-(-\beta(1-\alpha)) \cdot \beta \alpha \mathrm{E} \mathrm{Wo}(17)$

if $\Theta=\beta(1-\alpha)$ (18),

then :

$\mathrm{Wr}=\Phi(\mathrm{Wu}-\mathrm{C}+\beta \mathrm{E} \mathrm{Wo})-(-\Theta) \beta \alpha \mathrm{E}$ Wo (19)

$\mathrm{Wr}=\Phi(\mathrm{Wu}-\mathrm{C}+\beta \mathrm{EWo})+\Theta(\beta \alpha \mathrm{E} \mathrm{Wo})$

Furthermore, job seekers will be faced with the probability of working mathematically written as follows [3]:

$P=\frac{W_{k}-W_{r}}{W_{k}-W_{o}}$

$P=\frac{\mathrm{Wk}-\Phi(\mathrm{Wu}-\mathrm{C}+\beta \mathrm{E} \mathrm{Wo})+\Theta(\beta \alpha \mathrm{E} \mathrm{Wo})}{W_{k}-W_{o}}$

If returned

$\mathrm{Wo}=\mathrm{Wm}$

$P=\frac{\mathrm{Wk}-\Phi(\mathrm{Wu}-\mathrm{C}+\beta \mathrm{EWm})+\Theta(\beta \alpha \mathrm{E} \mathrm{Wm})}{W_{k}-W_{m}}$

$P=f(W k, W u, C, W m)$

If $\mathrm{Wu}=\mathrm{Iu}$

Then $P=f(W k, I u, C, W m)$

The probability of working a job seeker is influenced by wages that match the characteristics of individual job seekers, non-market wages received by job seekers while looking for work, the cost of looking for work, expectations of wages offered and market wages of individual job seekers. Previous studies that explain the application of search theory include the study of [7], which resulted in the finding that expected wages affect the length of time looking for work. In another study, [8] formulated a model that allows for the reservation wage (WR) and the job supply function $\mathrm{F}(\mathrm{W})$, varying according to the length of time looking for work. [9] found that the level of education significantly affects the length of time looking for work because the return is higher. [10] using the Kiefer-Neuman model found that the education of a female partner affects the reservation wage, [11] in a survey of migrant and non-migrant workers in Australia found that the unemployment rate would be lower for migrants who less educated than the indigenous population with low education. [12] suggests that prosperity, unemployment insurance and the business cycle affect the probability of working [13], found that job seeker benefits will affect the length of time looking for work.

\subsection{Research Objectives}

To determine the effect of the variables of age, gender, status as head of the household, income of job seekers during the period of looking for work, education and market wages on the probability of working in order to determine the probability of looking for job.

The contribution of this research is to give information for jobseekers about labor market condition and to help the decision maker in the work force policy in central java.

\subsection{Conceptual Framework}

Base on the concept of determining the probability model of looking for job, which is shown by the equation, $\mathrm{P}=\mathrm{f}(\mathrm{Iu}, \mathrm{C}, \mathrm{Wm}, \mathrm{Wk})$, then the model that will be built in this research is a model that shows the effect of wage characteristics, cost of looking for a job, income job seeker and Wage of market toward probability of looking for job. The variable development occurs because the wage characteristics in the proxy with the characteristics of job seekers include age, gender and education, costs will be represented by the status of job seekers as household heads and market wages will be categorized into 3 categories, namely wages market in areas with average wages in the high, medium and low categories. The conceptual framework of this research is shown in Figure 1

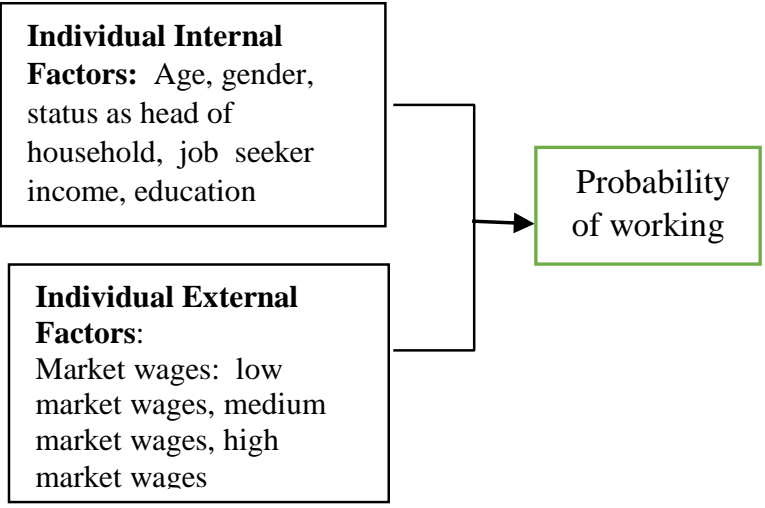

Figure 1. Conceptual Framework

\subsection{Hypotheses}

Based on the problem formulations, research objectives, theoretical framework, and the relationship between variables, the research hypothesis are:

1. Age has a negative effect on the probability of working. 
2. Male workforce will have a greater probability of working.

3. The labor force with the status of the head of the household will have a greater probability of working

4. The labor force that has income while looking for work will have a smaller probability of working

5. The level of education will have a negative effect on the probability of working.

6. The labor force in areas with higher Market Wages will have a lower probability of working

\section{METHODOLOGY}

The method used in this research is survey research by taking respondents from the national labor force survey sample for the province of Central Java, totaling 1646 respondents. Data collection was carried out by the Central Bureau of Statistics Indonesia.

\subsection{Collecting Data}

The data is taken directly from the source of the Central Bureau of Statistics by selecting the Labor Force respondents for the province of Central Java with 1646 respondent.

\subsection{Analysis Data}

Furthermore, it will be observed for groups of working respondents and job seekers as well as the characteristics attached and written in the questionnaire. With the help of the SPSS program, all the required data can be fulfilled.

Based on equality Probability of working, then the equation that will be used in this study is:

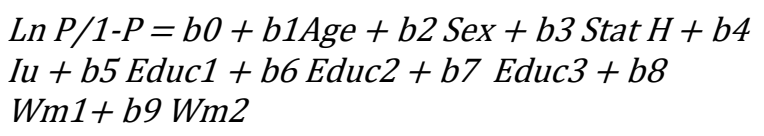

\section{RESULTS AND DISCUSSION}

Based on table 1, the average age of job seekers is 27 years old, the youngest is 15 years old and the oldest is 65 years old, which means there are some job seekers who spend all their normal working time looking for work. The lowest wage is IDR 50,000 per person and the highest is $63,000,000$, this shows that there is a high gap in real wage payments. The shortest duration of looking for work is 0 months, the longest is 108 months. The average length of time looking for work is 8,994 months. For the income of job seekers while looking for work, the highest is 3.9 million and the average is 157379 , the following is the relationship between age, status in the household, gender, education level and length of time looking for work (Duration of looking for work).

Table 1. Respondents by age, market wages, length of time looking for work and income While looking for work

\begin{tabular}{|l|c|l|l|l|}
\hline Variable & $\mathrm{N}$ & Min & Max & Average \\
\hline Age & 1646 & 15 & 65 & 27 \\
\hline Market Wage & & 500000 & 63000000 & 776716,5 \\
\hline Duration & 1646 & 0 & 108 & 8,994 \\
\hline $\begin{array}{l}\text { Income } \\
\text { Unemployment }\end{array}$ & 1646 & 0 & 4900000 & 157379 \\
\hline
\end{tabular}

Source: Central Bureau of Statistics

Table 2. Relationship Age, Status as Head of the Household, Gender Education level and market wages by Duration or length of looking for work

\begin{tabular}{|c|c|c|c|}
\hline \multirow[t]{2}{*}{ Variable } & \multicolumn{3}{|c|}{ Duration } \\
\hline & Mean & Monimum & Maximum \\
\hline Age & & & \\
\hline$<20$ & 6,71 & 0 & 60 \\
\hline $20-30$ & 11,31 & 0 & 97 \\
\hline$>30$ & 8,82 & 0 & 108 \\
\hline As a head o & & & \\
\hline status & 8,52 & 0 & 84 \\
\hline Not As a & 010 & & 100 \\
\hline $\begin{array}{l}\text { houshold } \\
\text { status }\end{array}$ & 9,12 & 0 & 108 \\
\hline Sex & & & \\
\hline Male & 9,42 & & \\
\hline Female & 8,07 & & \\
\hline Educ: & & & \\
\hline Educ1 & 7,33 & 0 & 84 \\
\hline Educ2 & 9,85 & 0 & 96 \\
\hline Educ3 & 8,57 & 0 & 108 \\
\hline Educ4 & 13,43 & 0 & 82 \\
\hline Wm: & & & \\
\hline Wm1 & 9,42 & 0 & 74 \\
\hline $\mathrm{Wm} 2$ & 8,06 & 0 & 108 \\
\hline $\mathrm{Wm} 3$ & 9,84 & 0 & 88 \\
\hline
\end{tabular}

Source: Central Bureau of Statistics

The results of the descriptive analysis is presented in the Table 2. Relationship Age, Status as Head of the Household, Gender Education level and market wages by Duration or length of looking for work. There is a tendency that the older you are, the longer it takes to look for work, those with the status of head of household are getting shorter in looking for work, men are looking for work longer, the higher the education level the longer it takes to find work. The higher the market wage, the longer it takes to find work because high market wages will trigger an increase in the reservation wage or expected wage.

The results of the inference analysis are shown in the table 3. 
Table 3. Variable in the equation

\begin{tabular}{|c|c|c|c|c|c|c|}
\hline Variable & B & SE & Wald & Df & Sig & $\begin{array}{c}\text { Exp } \\
(B)\end{array}$ \\
\hline Age & $-0,005$ & 0,001 & 38,480 & 1 & 0,00 & 0,99 \\
Sex & 0,569 & 0,032 & 325,588 & 1 & 0,00 & 1,77 \\
StatH & 0,952 & 0,038 & 639,249 & 1 & 0,00 & 2.59 \\
Income & 0,000 & 0,000 & 76,903 & 1 & 0,00 & 1.00 \\
Educ1 & $-0,565$ & 0,036 & 245,061 & 1 & 0,00 & 0,56 \\
Educ2 & $-0,381$ & 0,039 & 96,164 & 1 & 0,00 & 0,68 \\
Educ3 & $-0,231$ & 0,077 & 9,058 & 1 & 0,003 & 0,79 \\
Wm1 & $-0,202$ & 0,027 & 54,197 & 1 & 0,000 & 0,82 \\
Wm2 & $-1,033$ & 0,047 & 486634 & 1 & 0,000 & 0,36 \\
Constant & $-0,118$ & 0,047 & 6,322 & 1 & 0,012 & 0,89 \\
& & & & & & \\
\hline
\end{tabular}

Variable(s) entered on step 1: Age, Sex, StatH, UIncome, educ1, educ2, educ3,,Wm1_Wm2

Stat $\mathrm{H}=$ status Of respondent as ahead of house hold or not Income $=$ Unemployment Income

There is a tendency that the older you are, the longer it takes to look for work, those with the status of head of household are getting shorter in looking for work, men are looking for work longer, the higher the education level the longer it takes to find work. The higher the market wage, the longer it takes to find work because high market wages will trigger an increase in the reservation wage or expected wage.

Men have a greater probability of working so they will have a smaller probability of looking for work than women. The difference that occurs is significant at 1 percent. This is not consistent with the descriptive findings which show that men spend longer in the job search, because the low probability of looking for work in the male workforce indicates that the workforce has a shorter time looking for work. The labor force with the status of the head of the household has a greater probability of working, so it will have a lower probability of looking for work than the labor force with the status of not being the head of the household. The difference is significant at 1 percent. This is consistent with descriptive findings which show that the workforce with the status of the head of the household will spend less time looking for work, Men have a greater probability of working so they will have a smaller probability of looking for work than women. The difference that occurs is significant at 1 percent. This is not consistent with the descriptive findings which show that men spend longer in the job search, because the low probability of looking for work in the male workforce indicates that the workforce has a shorter time looking for work. Income while looking for work for the labor force will prolong the period of looking for work because the probability of working in the labor force with income is the same as the probability of working in the labor force without income. The findings show that differences in income do not result in differences in the probability of working. The workforce with junior high school, high school and college education has a smaller probability of working so that they will have a greater probability of looking for work than the workforce with elementary school education. The difference is significant at 1 percent. This is consistent with descriptive findings which show that the higher the level of education, the longer the period of looking for work, because the greater probability of looking for work in the workforce with junior high school, high school and college education indicates that the workforce is in the search for work longer.

The labor force in areas with medium and high market wages, namely $\mathrm{Wm} 1$ and $\mathrm{Wm} 2$, has a smaller probability of working so that they will have a greater probability of looking for work than the labor force in areas with a low average market wage category. Differences that occurs is significant at 1 percent. This is consistent with descriptive findings which show that the higher the market wage, the longer they will be in the search for work, because the greater probability of looking for work in the workforce indicates that they are in the search for work longer. The probability of working and the probability of looking for work according to age, gender, status as head of household, income while looking for work, education level of junior high school, senior high school and university as well as market wages will be determined which is also presented in table 4 .

Table 4. Probability of looking for job

\begin{tabular}{|l|c|r|}
\hline & $\mathrm{P}$ & $1-\mathrm{p}$ \\
\hline constanta & 0,047053 & 0,052947 \\
\hline Age & 0,046929 & 0,053071 \\
\hline SEX & 0,061088 & 0,038912 \\
\hline Stat H & 0,06972 & 0,03028 \\
\hline Income & 0,047053 & 0,052947 \\
\hline Educ1 & 0,033559 & 0,066441 \\
\hline Educ2 & 0,037778 & 0,062222 \\
\hline Educ3 & 0,041362 & 0,058638 \\
\hline Wm1 & 0,042068 & 0,057932 \\
\hline Wm2 & 0,024031 & 0,075969 \\
\hline Total & 0,450641 & 0,549359 \\
\hline
\end{tabular}

Source: Central Bureau of Statistics

\section{CONCLUSION}

From the results of the analysis it can be concluded that the probability of working in the older workforce is smaller so that the probability of looking for work will be greater, the male workforce has a greater probability of working than women so that it will have a smaller probability of looking for work, individuals with status as the head of the household has a greater 
probability of working than those who are not the head of the household, the probability of working for job seekers have income will be smaller, approaching the same as those without income so that it will show the probability of looking for work which tends to be greater, the educated workforce is more high workers tend to have a smaller probability of working so that the probability of looking for work will also be greater, at higher market wages they tend to have a lower probability of working so that the probability of looking for work is also tend to be larger. These findings are in accordance with the hypothesis and assumptions in the search theory.

All of the variables involved are appropriate to be used in the framework of formulating work and job seeking models because all variables have a significant effect on the probability of working. This research should be able to reveal the size of the reservation wage set by job seekers if it is available in the Sakernas data, or researchers are able to conduct field research with respondents who can represent the province of Central Java. On the other hand, this research should be able to add to the study of the role of the family in supporting job seekers during the period of looking for work, if it does not have the time, cost and energy limitations needed to reach respondents throughout Central Java.

The theoretical implication shows that the independent variables included in the model are feasible to be used as variables that can be used to build a working probability model as well as being able to predict the probability of finding work for the workforce in Central Java.

The policy implication of this research is to encourage stakeholders to direct education that produces alumni according to competent standards equipped with a salary system that is adjusted to the level set at each level of competence, expand access to capital and facilitate the granting of business permits for new entrepreneurs involving the private sector. and the community, besides expanding access to information, it is important for job seekers who will look for work in areas with a high market wage environment, reducing or eliminating the cost of processing documents for job search requirements, so as to reduce the cost burden for job seekers with the status of head of household.

The future agenda is to conduct field research that is able to examine the variables that represent the characteristics of respondents, which can support an increase in the reservation wage.

\section{AUTHORS' BIOGRAPHIES}

Dody Setyadi, is a senior Lecturer in the international business management study program, Business Administration Department, Politeknik Negeri Semarang (Polines), Indonesia. Currently he has additional duties as Head of the Department of Business Administration. He can be contacted at ds_polnes@yahoo.com.

Karnowahadi, is a senior lecturer at the Business Administration Department, Politeknik Negeri Semarang (Polines), Indonesia. currently he has additional duties as Head of the Learning Development Center, as Editor in Chief of Polines' Admissions and Business journal. He can be contacted at karnowahadi@polines.ac.id.

Endang Sulistiyani, Lecturer at Business Administration Department, Politeknik Negeri Semarang (Polines), Indonesia. Currently, she has additional duties as a team on the editorial board of the Admissions and Business journal owned by Polines. She can be contacted at endangsulis15@polines.ac.id.

\section{ACKNOWLEDGMENTS}

Thank you to co-author coribtuntion $\mathrm{Mr}$ Karnowahadi and Mrs Endang Sulistyani. Thank you to Politeknik Negeri Semarang for facilitating us to be presenters at this seminar. Thank you also to the Seminar Committee for accepting this article to be presented in this forum.

\section{REFERENCES}

[1] G.J. Stigler, "The Economics of Conflict of Interest," Journal of Political Economy, University of Chicago Press, vol. 75, pp. 100100, 1967.

[2] J. J. McCall, "Economics of Information and Job Search," The Quarterly Journal of Economics, vol. 84, no. 1, pp. 113-126, 1970

[3] T. J. Fitzgerald, "An Introduction to the Search Theory of Unemployment," Ecnomic ReviewFederal Reserve Bank Of Cleveland, vol. 34, pp. 2-15, 1998

[4] K. Burdett, "A Theory of Employee Job Search and Quit Rates," The American Economic Review, pp. 212-220, 1978.

[5] G.S Becker, The Economic Approach to Human Behavior. University of Chicago Press, 1976 
[6] K. Burdett, and K. Judd, "Equilibrium Price Distributions," Econometrica, vol. 51, pp. 955970, 1983.

[7] Feinberg, and M. Robert, "On the Empirical Importance of the Job Search Theory," Southern Economic Journal, vol. 45, no. 2, pp. 508 - 521, 1978.

[8] N. Kiefer, and G.R. Neumann, “An Empirical Job-Search Model, with a Test of the Constant Reservation-Wage Hypothesis", Journal of Political Economy, vol. 87, issue 1, pp. 89-107, 1979.

[9] P.R. Fallon, Education and the duration of job search and unemployment in urban India. Journal of Development Economics, vol. 12, pp. $327-340,1983$.

[10] M.R. Montgomery, and D.B. Sulak, "Female first marriage in East and Southeast Asia : A Kiefer-Neumann model," Journal of Development Economics, Elsevier, vol. 30(2), pp. 225-240, 2989

[11] J.J. Beggs, and B.J. Chapman, "Search efficiency: Skill Transferability and Immigrant Relative Unemployment Rates in Australia," Applied Economics, vol. 22 (2), pp. 249 - 260, 1990.

[12] D. Andolfatto, and M. Gervais, "Human Capital Investment and Debt Contraints," Review of Economic Dynamics, vol. 9, issue 1, pp. 52-67, 2006.

[13] B.S. Bieszk, and I. Markowicz, "Relationship Between Duration Of Job Seeking and Receiving Unemployment Benefit," Search Theory On Labour Market,Actauniversitatislodziensis, Folia Oeconomica, vol. 3(302), pp. 193 - 201, 2014. 